\title{
Artificial photoperiod: it's influence on mare's autumn transition period and seasonal anestrus
}

\author{
Fabíola Freire Albrecht de David*, João Francisco Weber Bisol*, Roberta Mayer Evangelista, Ivan Cunha Bustamante-Filho, Caroline \\ Antoniazzi Wolf, Ricardo Macedo Gregory, Maria Inês Mascarenhas Jobim and Rodrigo Costa Mattos
}

REPROLAB, Departamento de Medicina Animal, FAVET, UFRGS, Porto Alegre, Brazil

\begin{abstract}
Summary
The aim of this work was to determine if an artificial photoperiod program starting in early or late summer can delay the onset of autumn transition. Two experiments were performed in the southern hemisphere. Thirteen and seventeen nonlactating mares were used in the first and second experiments, respectively. In the first experiment, 8 mares were submitted to an artificial photoperiod from February, 23rd while in experiment two 7 mares received artificial lighting from 15 January. Five and 10 mares were exposed to natural photoperiod and served as controls for each group respectively. Mares were examined by means of rectal palpation and ultrassonography in order to evaluate ovarian activity. Body conditions were also evaluated. Blood samples were obtained for progesterone determination. It was concluded that artificial lighting beginning in the first month of the summer was effective to maintain cyclicity of treated mares.

Keywords: mare, reproduction, artificial photoperiod, autumn transition, anestrus

\section{Künstliches Lichtprogramm: Sein Einfluss auf die Übergangsphase im Herbst und auf den saisonalen Anöstrus}

In der Studie sollte untersucht werden, ob ein künstliches Lichtprogramm, begonnen im Früh- oder Spätsommer, den Beginn der Übergangsphase im Herbst verzögert. Zu diesem Zweck wurden auf der südlichen Halbkugel zwei Experimente durchgeführt. Die Studienpopulation bestand für den ersten Versuch aus 13 und für den nachfolgenden aus 17 nicht-laktierenden Stuten. Im ersten Experiment wurden 8 Stuten beginnend am 23. Februar einem Lichtprogramm unterzogen. Dies erfolgte im zweiten Versuch bei 7 Stuten ab dem 15. Januar. Fünf bzw. zehn Stuten dienten für den jeweiligen Versuch als Kontrollgruppe. Diese Tiere unterlagen einer natürlichen Photoperiode. Um die ovarielle Aktivität zu überprüfen erfolgten rektale und ultrasonographische Untersuchungen. Ebenso wurde die Körperkondition erfasst. Des Weiteren wurden für die Bestimmung der Progesteronkonzentration Blutproben gewonnen. Es wird geschlußfolgert, dass das künstliche Lichtprogramm - beginnend im ersten Monat des Sommers - für die Aufrechterhaltung der Zyklusaktivität effektiv war.
\end{abstract}

Schlüsselwörter: Stute, Reproduktion, künstliches Lichtprogramm, Übergangsphase im Herbst, Anöstrus

\section{Introduction}

Photoperiod is in the forefront of the environmental factors affecting equine reproductive seasonality (Ginther 1992). The change in daylight hours at various times of the year is a potent environmental factor that alters $\mathrm{GnRH}$ production indirectly through the pineal gland (Bergfelt 2000). Light is perceived by the retina of the eyes, resulting in messages that are transmitted to the pineal gland influencing the secretion of melatonin (Ginther 1992). Decreased ovarian activity was associated with increased pineal activity, and ovarian activity was not restored until well after pineal activity had decreased. Pineal melatonin-forming activity is temporally related to reproductive seasonality (Ginther 1992). In the mare, short daylight is associated with a decrease in gonadotropin secretion and presumably $\mathrm{GnRH}$ secretion and consequently a decrease in ovarian activity (Nagy et al. 2000).

Autumn transition and seasonal anestrus are of great importance in equine breeding management. During transition into anestrus, mares may have fluctuations in FSH levels, while the LH surge, responsible for follicle ovulation, is absent (Sharp and Davis 1993). As a consequence, autumn transition is normally marked by inconstant follicular dynamics and variable behavior. During this period there are negative effects in follicular growth rate, size and divergence (Nunes et al. 2002). For this reason, ovarian abnormalities, such as anovulatory hemorrhagic follicles are often present (Pycock 2000).

Previous work has shown that the breeding season may be extended for one or two months by providing an Artificial artificial lighting regimen near the end of the ovulatory season (Guinther 1992). Although extending the cyclicity into the fall is not a common practice in most stud farms, it can be advantageous for selected problem mares when additional time for treatment is needed. Similarly, in embryo transfer programs, the possiblitily to avoid seasonal anestrus can be advantageous. Use of donnor and recipient mares during the whole year could optimize the production of foals by this technique.

The aim of this work was to verify if an artificial photoperiod starting in early or late summer can delay the onset of autumn transition.

\section{Material and methods}

\section{Experiment 1}

Thirteen nonlactating Brazilian Sport Horse mares aged between 4 and 10 years old were used in this experiment. The experiment was performed in São Boria, RS, Brazil $\left(28^{\circ} 44^{\prime} \mathrm{S}\right.$ 
and $55^{\circ} 35^{\prime} \mathrm{W}$ ) during the breeding season. All mares were healthy and kept on pasture with free access to water and trace-mineralized salt. In the beginning of the experiment, all mares were in the ovulatory season as indicated by detection of a preovulatory follicle and subsequent ovulation on ultrasound scanning.

Animals were randomly split in two groups: Late Treatment (LT, $\mathrm{n}=8$ ) - mares were submitted to an artificial photoperiod (10 $\mathrm{W} / \mathrm{m} 2$ ) with $15 \mathrm{~h}$ light and $9 \mathrm{~h}$ darkness (15L:9D) from February, 23rd until September 21; and Control $(n=5)-$ mares were kept under natural photoperiod.

Mares were examined weekly by means of rectal palpation and ultrasound (Aloka SSD500 with $5 \mathrm{MHz}$ probe) in order to evaluate ovarian activity. The body condition of each mare was evaluated weekly using a score varying from 1 to 5 (Malschitzky et al. 2001). Also, blood samples were obtained for progesterone determination by radioimmuneassay (ImmunoChemTM Progesterone CT, California, USA). Anestrus was defined as no ovarian activity (follicles less than $15 \mathrm{~mm}$ ) in combination with progesterone concentrations of less than 1 $\mathrm{ng} / \mathrm{mL}$ for at least 21 days.

\section{Experiment 2}

This experiment was performed in Alegrete, RS, Brazil $\left(29^{\circ} 40^{\prime} \mathrm{S}\right.$ and $\left.56^{\circ} 16^{\prime} \mathrm{W}\right)$, during the breeding season. Seventeen nonlactating Brazilian Sport Horse mares aged between 14 to 22 years old were used in this experiment.

All mares were healthy and kept on pasture with free access to water and trace-mineralized salt. In the beginning of the experiment, all mares were in the ovulatory season as indicated by detection of a preovulatory follicle and subsequent ovulation on ultrasound scanning.

Animals were randomly split in two groups: Early Treatment $(E T, n=7)$ - mares were submitted to an artificial photoperiod
$(10 \mathrm{~W} / \mathrm{m} 2)$ with $15 \mathrm{~h}$ light and $9 \mathrm{~h}$ darkness (15L:9D) from January, 15th until September 21; and Control $(n=10)-$ mares were kept under natural photoperiod.

Mares were examined twice a week by means of rectal palpation and ultrasound (Aloka SSD500 with $5 \mathrm{MHz}$ probe) in order to evaluate ovarian activity. The body condition of each mare was evaluated weekly using a score varying from 1 to 5 (Malschitzky et al 2001). Also, blood samples were taken for progesterone determination by radioimmuneassay (ImmunoChemTM Progesterone CT, California, USA). Anestrus was defined as no ovarian activity (follicles less than $15 \mathrm{~mm}$ ) in combination with progesterone concentrations of less than 1 $\mathrm{ng} / \mathrm{mL}$ for at least 21 days.

\section{Statistical analysis}

For statistical analysis ANOVA was used to compare the interval from the beginning of the experiments until the last ovulation and until the beginning of anestrus, the mean of ovulations during the experiments and the mean length of the oestrus cycle. Student's t test for independent samples weretest for independent samples was used to compare the number of ovulations, mean cycle length and the number of days from the beginning of artificial photoperiod regimen to the last ovulation. Chi-square (X2) was used to verify the difference of diestrus length between the two groups. All statistical analysis werewas performed using Graphpad Instat 3.0, and significance was set at $p<0.05$. Pearson correlation was used to compare the body condition and the cycle length in experiment 2 .

\section{Results}

\section{Experiment 1}

All the 13 mares demonstrated anestrus. The results from this experiment are described in Table 1. During the transitional

Table 1 Intervals in days from beginning of artificial photoperiod treatment to last ovulation and to beginning of anestrus; length of $\mathrm{CL}$ and distribution of mares regarding the length of the last diestrus. Data represented as mean $\pm S D$.

\begin{tabular}{lcc}
\hline & Treatment Group & Control Group \\
Interval -to-last-ovulation (days) & $40.4 \pm 19.4$ & $46.2 \pm 29.1$ \\
Interval -to-anestrus (days) & $70.6 \pm 14.8$ & 0.67 \\
Number of mares with last diestrus $>15$ days & $6^{\mathrm{a}}$ & $67.8 \pm 22.8$ \\
Number of mares with last diestrus $\leq 15$ days & $2^{\mathrm{b}}$ & $2^{\mathrm{x}}$ \\
${ }^{\mathrm{a}, \mathrm{b}}\left(X^{2}=4,0\right)-$ different superscripts in the column represent statistical significance $(P=0.04) .{ }^{\times}\left(X^{2}=0,4\right)$ - equal superscripts in the column represent absence of \\
statistical significance $(P=0.52)$.
\end{tabular}

Table 2 Intervals in days from beginning of artificial photoperiod treatment to last ovulation and to beginning of anestrus, number of ovulations and mean cycle length, Data represented as mean \pm SD.

\begin{tabular}{lcc}
\hline & Treatment & Control \\
\cline { 2 - 3 } Interval -to-last-ovulation (days) & $210 \pm 50.6$ & $118 \pm 62.6$ \\
Interval -to-anestrus (days) & $166 * 005$ \\
Cycle length (days) & $24.4 \pm 1.51$ & $123.63 \pm 23.19$ \\
Number of ovulations & $9.29 \pm 1.98$ & $34.04 \pm 24.77$ \\
"Single mare from Treatment Group that presented anestrus. Diestrus ovulations were not included in the results. & $4.9 \pm 2.85$ \\
\hline
\end{tabular}


phase, three different conditions were observed: (1) 8 mares presented a persistent CL prior anestrus (Treatment group - 6, Control group - 2); (2) 4 mares entered in anestrus after luteolysis of a regular CL (two of each group); (3) one mare showed a diestrus for 8 days with progesterone lower than 1 $\mu \mathrm{g} / \mathrm{mL}$.

No difference $(p=0.79)$ was observed in the interval from beginning of the experiment to last ovulation between the treated mares $(40.4 \pm 19.4)$ and the control group (46.2 \pm 29. 1). Also no difference ( $p=0.67)$ was detected in the inter$\mathrm{val}$ between the beginning of the experiment to the detection of anestrus in both groups (70.6 \pm 14.8 vs $67.8 \pm 22.8)$.

\section{Experiment 2}

The treatment group had a higher $(p<0.05)$ number of mares cycling until the end of the experimental period (September 15) in comparison to the control group $(85.71 \%$ and $20 \%$ respectively). A significant difference $(p=0.005)$ was observed in the interval from beginning of the experiment to last ovulation between the treated mares (210 \pm 50.6 days) and the control group (1 $18 \pm 62.6$ days). The cycle length did not differ between groups, however the number of ovulations during the experiment was greater $(p=0.002)$ in the treated mares (9.29 \pm 1.98 days) when compared with the control mares $(4.9 \pm 2.85$ days). The results from this experiment are described in Table 2.

The relationship between body condition and cycle length from the treated mares are expressed in Figure 1. A negative correlation $(r=-0.44)(p=0.24)$ was observed.

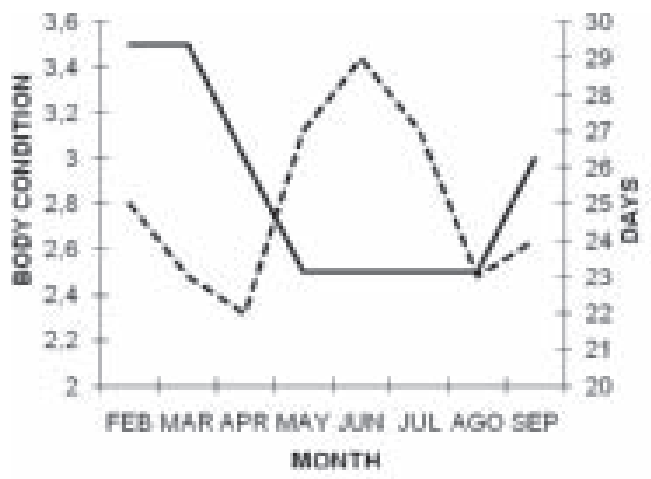

Fig 1 Monthly variation of body condition (-) and length of the cycle (----) of the mares during the experiment.

\section{Discussion}

The present paper demonstrates that the tested regimen of artificial lightning (AL) (15L:9D: 9D) is effective to prevent winter anestrus when initiated in early summer. However, if the same treatment is applied later in the summer, it has no effect on seasonal cyclicity of mares.

In experiment one, when the $\mathrm{AL}$ was tested in late summer, the absence of response to treatment could be due to the already lower daylight. In February 23rd, daylight was already reduced to $63.7 \%$ of the expected daylight of beginning of autumn. This fact could have triggered the circannual endogenous reproductive rhythm, inducing the entering in transitional phase.

All mares in this experiment entered anestrus, although other authors affirm that a proportion of mares do not enter in anestrus during winter (Hughes et al. 1976, Nequin et al. 2000, Tarouco et al. 1995) or under effect of natural or artificial photoperiod (Scraba and Guinter 1985, Palmer and Guillaume 1992). During the transitional phase, three different conditions were observed: (1) 8 out of 13 mares presented a persistent CL prior anestrus (Treatment group - 6, Control group - 2); (2) 4 mares entered in anestrus after luteolysis of a regular CL (two of each group); (3) one mare showed a diestrus for 8 days with progesterone lower than 1 $\mu \mathrm{g} / \mathrm{mL}$. These findings agree with King et al. (1993), who described these events as characteristic for the transitional phase. However, the authors cite the follicular growth followed by atresia as another occurring event in transitional phase, but this was not identified in the present work.

Persistent CLs were observed in $40 \%$ of the Control group, in accordance with the findings of Nequin et al. (2000) who established that 1/3 of mares entering anestrus develop a persistent $\mathrm{CL}$. Conversely, $75 \%$ of mares exposed to $\mathrm{AL}$ presented persistent $\mathrm{CL}$, and this fact might be related to the decreasing concentration of estradiol during the transitional phase. Since PGF2 $\alpha$ secretion by the endometrium is regulated by estradiol (Vernon et al. 1981), its impaired secretion might be responsible for the persistent CL.

In experiment two, the number of treated animals that maintained reproductive cyclic activity was higher than the number of mares that continued cycling in Control group. This result does not agree with those obtained by Kooistra and Ginther in 1975, in which mares kept under stimulating photoperiod over a year from summer solstice, presented an anovulatory phase. Even though the experiment of Kooistra and Ginther (1975) began in the summer solstice, it did not succeed to stop winter's anovulatory phase, even in the mares that did receive nutritional supplement. Apparently, the temperatures from the southern Wisconsin's winter influenced negatively the effect of $A L$, while in this study,study; winter's positive temperatures close to $0^{\circ} \mathrm{C}$ could have contributed for prolonged cycles.

It is known that several factors interact, in some level, with the effect of photoperiod, even though this is a crucial factor on mare's reproductive seasonality (Sharp 1980). Among the most important are animal's nutritional status and regional temperatures (Ginther 1974).

In spite of the fact that the photoperiod treatment was sufficient to maintain cyclicity, irregularities in the cycles from all treated animals were observed, especially between the end of April and June. At this time, both animals that remained cyclic in the control group also presented prolonged cycles. In both groups the delayed divergence was the main factor for the prolongation of cycles in mares which did not entered anestrus. Nutritional deficiencies have already been implicated on the regulation of reproductive endocrinal factors (Kubiak et al 1987, Sticker et al. 1995a, Sticker et al. 1995b, Car- 
nevale et al. 1996, Gentry et al. 2002). In mares fed with a low energy diet or protein during the winter, Sticker et al (1995a) observed diminished IGF-1 secretion, an important factor for follicular development. In mares, IGF-1 and its receptors increase specifically in the dominant follicle before divergence (Doyle et al. 2008), making it possible to attribute a special role to IGF-1 in the selection and subsequent development of ovulatory follicles (Ginther et al. 2004).

No animal from the present study received nutritional supplementation; therefore winter's pasture could have been deficient in nutrients required for an adequate reproductive function. Body weight loss, even non excessive could have altered leptin circulating levels, which plays an indirect role on reproductive activity (Fitzgerald and McMannus 2000). Gentry et al. (2002) demonstrated lower levels of IGF-1, leptin, progesterone and prolactin in mares kept at 3.0-3.5 body score (range from 1 to 9) compared to those with a 7.5-8.5 body score (ranging from 1 ato 9); however, the same authors suggested that in mares with good body condition, apparently high levels of leptin is not a sign of interruption of the reproductive cycle.

It was observed that when the cycle length increased, body condition had already decreased. The fact that prolongation of the estrous cycle in treated animals begun approximately at the same time as when control animals entered anovulatory phase, could be a sign that nutrition and temperature reached a crucial level. Thus, culminating in the cessation of reproductive activity in the majority of control mares, but not in treated mares. There was a difference in the number of ovulations and the interval between the beginning of the treatment and the last ovulation, but not in the length of the cycle.

It was concluded that artificial lighting beginning in the first month of the summer was effective to maintain the cyclicity of treated mares.

\section{References}

Bergfelt D. R. (2000) Estrous synchronization. In: Samper J Equine breeding management and artificial insemination. W. B. Saunders, Philadelphia, pp 165-177

Carnevale E. M., Hermenet M. J. and Ginther O. J. (1996) Age and pasture effects on vernal transition in mares. Theriogenology 47 , 1009-1018

Doyle I. K., Hogg C. O., Watson W. D. and Donadeu F. X. (2008) Seasonal effects on the response of ovarian follicles to IGFI in mares. Reproduction 136, 589-598

Fitzgerald B. P. and McManus C. J. (2000) Photoperiodic versus metabolic signals as determinants of seasonal anestrus in the mare. Biol. Reprod. 63, 335-340

Gentry L. R., Thompson J. R., Gentry J. R., Davis K. A., Godke R. A. and Cartmill J. A. (2002) The relationship between body condition, leptin, and reproductive and hormonal characteristics of mares during the seasonal anovulatory period. J. Anim. Sci. 80, 26952703

Ginther O. J. (1974) Ocurrence of anestrus, estrus, diestrus, and ovulation over a twelve-month period in mares. Am. J. Vet Res. $35,1173-1179$

Ginther O. J. (1992) Reproductive Biology of the Mare, ed. Equiservices, Cross Plains
Ginther O. J., Gastal E. L., Gastal M. O. and Beg M. A. (2004) Critical role of insulin-like growth factor system in follicle selection and dominance in mares. Biol. Reprod. 70, 1374-1379.

Hughes J. P., Stabenfeldt G. H. and Evans J. W. (1975) The oestrus cycle of a mare. J. Reprod. Fertil. Suppl. 23, 161-166

King S. S, Neumann K. R., Nequin L. G. and Weedman B. J. (1993) Time of onset and ovarian state prior entry into winter anestrus. J. Eq. Vet. Sci. 13, 512-515

Kooistra L. H. and Ginther O. J. (1975) Effect of photoperiod on reproductive activity and hair in mares. Am. J. Vet Res 36, 14131419

Kubiak J. R., Crawford B. H., Squires E. L., Wrigley R. H. and Ward G. M. (1987) The influence of energy intake and percentage of body fat on the reproductive performance of nonpregnant mares. Theriogenology 28, 587-598

Malschitzky E., Schilela A., Meirelles L.S., Mattos A. L. G., Gregory R. M. and Mattos R. C. (2001) Artificial photoperiod in pregnant mares and its effect on pregnancy length and postpartum reproductive performance. Pferdheilkunde 17, 565-569

McCue P. M., Logan N. L. and Magee C. (2007) Management of the transition period: physiology and artificial period. Eq. Vet. Educ. 146-150

Nagy P. G., Guillaume D. and Daels P. (2000) Seasonality in mares. An. Reprod. Sci. 60-61, 245-262

Nunes M. M., Gastal E. L., Gastal M. O. and Rocha A. N. (2002) Influence of the autumn transitional phase on follicular development in mares. Theriogenology 58, 603-606

Nequin L. G., King S. S., Roser J. F., Soderstrom B. L., Carnevale E. M. and Neumann. K. R. (2000) Uncoupling of the equine reproductive axes during the transition into anestrus. J. Reprod. Ferlil., Suppl. 32, 153-161

Palmer E. and Guillaume D. (1992) Photoperiodism in the equine species - what's a long night? An. Reprod. Sci. 28, 21-30

Picock J. F. (2000) Breeding management of the problem mare. In: Samper J Equine breeding management and artificial insemination. W. B. Saunders, Philadelphia, pp 195-228

Scraba S. T. and Ginther O. J. (1985) Effects of lighting programs on onset of the ovulatory season in mares. Theriogenology 24, 667 679

Sharp D. C. (1980) Environmental influences on reproduction in horses. Vet. Clin. North Am. 2, 207-233

Sharp D. C. and Davis S. D. (1993) Vernal transition. In: Equine Reproduction. Ed. Lea \& Febiger, Philadelphia, pp 133-143

Sticker L. S., Thompson D. L. Jr., Fernandez J. M., Bunting L. D. and De Pew C. L. (1995a) Dietary protein and (or) energy restriction in mares: plasma growth hormone, IGF-1, prolactin, cortisol, and thyroid hormone responses to feeding, glucose, and epinephrine. J. An. Sci. 73, 1424-1432

Sticker L. S., Thompson D. L. Jr., , Bunting L. D., Fernandez J. M., De Pew C. L. and Nadal M. R. (1995b) Feed deprivation of mares: plasma metabolite and hormonal concentrations and responses to exercise J. An. Sci. 73,.3696-3704

Tarouco A. K., Hammes A. M. and Pimentel C. A. (1995) Estacionalidade reprodutiva de éguas abatidas em Pelotas - RS. Arq. Fac. Vet. UFRGS 23, 22-28

Vernon M. W. (1981) ProstaglandinF2 $\alpha$ in the equine endometrium: Steroid modulation and production capacities during the estrous cycles and early pregnancy. Biol. Reprod. 25, 581-589

Fabiola Freire Albrecht de David

REPROLAB

Departamento de Medicina Animal, FAVET, UFRGS

Porto Alegre, RS, Brazil

rcmattos@ufrgs.br 